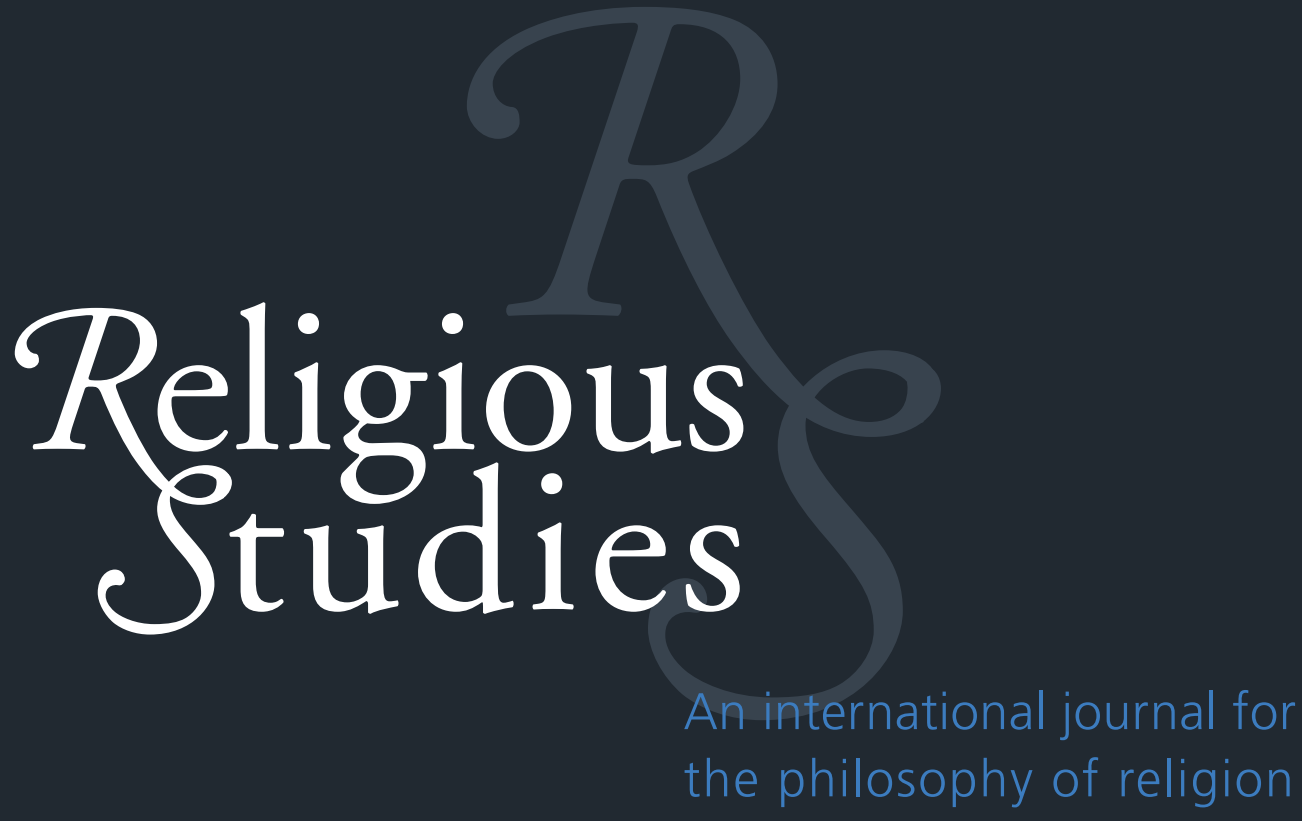

EDITOR: YUJIN NAGASAWA

This issue includes articles by

Dustin Crummett, Nikk Effingham, Philipp Kremers, Samuel Lebens, T. J. Mawson, Joe Milburn, Justin Mooney, Mark C. Murphy, Mohammad Saeedimehr, Jack Williams, Luke Wilson 


\section{Ręligious Studies}

\author{
An international journal for \\ the philosophy of religion
}

Editor

YUJIN NAGASAWA

University of Birmingham

Book reviews editor

TASIA SCRUTON

University of Leeds

Emeritus Editors

PETER BYRNE

DAVID EFIRD $\dagger$

ROBIN LE POIDEVIN

STEWART SUTHERLAND

KEITH WARD

MARK WYNN

\section{Editorial Board}

ANNA ROSA ANTOGNAZZa Kings College London

DAVID BASINGER Roberts Wesleyan College

JC BEALL University of Notre Dame

JOHN BISHOP University of Auckland

MIKEL BURLEY University of Leeds

ELIZABETH BURNS University of London

RYAN BYERLY University of Sheffield

CLAIRE CARLISLE King's College London

OLIVER D. CRISP University of St Andrews

SOPHIE-GRACE CHAPPELL Open University

HELEN DE CRUZ Oxford Brookes University

NATALJA DENG Yonsei University

JEANINE DILLER University of Toledo

PAUL DRAPER Purdue University

FIONA ELLIS University of Roehampton

JEROME GELLMAN Ben-Gurion University

CHRISTOPHER HAMILTON King's College London

VICTORIA HARRISON University of Macau

DANIEL HOWARD-SNYDER Western Washington University

TIMOTHY MAwson St Peter's College Oxford

THADDEUS METZ University of Johannesburg

WESLEY MORRISTON University of Colorado

MICHAEL MURRAY Templeton Foundation

GRAHAM OPPY Monash University

JOHN SCHELLENBERG Mount Saint Vincent University

MICHAEL SCOTT University of Manchester

THOMAS SENOR University of Arkansas

SONIA SIKKA University of Manchester

MEGHAN SULLIVAN University of Notre Dame

RICHARD SWINBURNE Oriel College Oxford

THOMAS TALBOTT Willamette University

PATRICK TODD The University of Edinburgh

EDWARD WIERENGA University of Rochester

Religious Studies is an international journal devoted to the problems of the philosophy of religion as these arise out of classical and contemporary discussions and from varied religious traditions. Space is devoted to articles, of which more than 25 are published each year, but the journal also contains a book review section, which may include review articles and shorter notes as well as normal-length reviews.

\section{Subscriptions}

Religious Studies (ISSN 0034-4125) is published four times a year in March, June, September and December. Four parts form a volume. The subscription price which includes delivery by air where appropriate, plus electronic access to institutional subscribers (but excluding VAT), of Volume 57 is $£ 419$ (USA $\$ 719$ in the USA, Canada and Mexico) for institutions and $£ 85$ (US \$141 in USA, Canada and Mexico) for individuals. Single parts are £118 (USA \$203 in USA, Canada and Mexico) plus postage. The electronic-only price available to institutional subscribers is $£ 353$ ( $\$ 618$ in USA, Canada and Mexico). EU subscribers may be required to pay import VAT at their country's rate on receipt of physical deliveries. EU subscribers for electronic deliveries who are not VAT registered should add VAT at their country's rate. VAT registered subscribers should provide their VAT number. Japanese prices for institutions (including AsP delivery) are available from Kinokuniya Company Ltd, P.o. Box 55, Chitose, Tokyo 156, Japan. Orders, which must be accompanied by payment, may be sent to a bookseller, subscription agent or direct to the publisher: Cambridge University Press, Journals Fulfillment Department University Printing House, Shaftesbury Road, Cambridge CB2 8BS, UK; or in the USA, Canada and Mexico: Cambridge University Press, Journals Fulfillment Department, One Liberty Plaza, Floor 20, New York, NY 10006, USA. Copies of the journal for subscribers in the USA, Canada and Mexico are sent by air to New York to arrive with minimum delay. Periodicals postage paid at New York, NY, and at additional mailing offices. Postmaster: send address changes in the USA Canada and Mexico to: Religious Studies, Cambridge University Press, One Liberty Plaza, Floor 20, New York, NY 10006, USA. Claims for missing issues should be made immediately on receipt of the subsequent issue.

\section{Copying}

This journal is registered with the Copyright Clearance Center, 222 Rosewood Drive, Danvers, MA 01923, USA (www.copyright. com). Organizations in the UsA who are also registered with c.c.c. may therefore copy material (beyond the limits permitted by sections 107 and 108 of us copyright law) subject to payment to c.c.c. This consent does not extend to multiple copying for promotional or commercial purposes. IsI Tear Sheet Service, 3501 Market Street, Philadelphia, P.A. 19104, USA, is authorized to supply single copies of separate articles for private use only. Organizations authorized by the Copyright Licensing Agency may also copy material subject to the usual conditions. For all other use, permission should be sought from Cambridge or the American Branch of Cambridge University Press.

\section{Internet access}

Information on Religious Studies and all other Cambridge journals can be accessed via cambridge.org/journals.

This journal issue has been printed on FSC-certified paper and cover board. FSC is an independent, non-governmental, not-for-profit organization established to promote the responsible management of the world's forests. Please see www.fsc.org for information.

(C) Cambridge University Press 2021 